\title{
Coping in mental health during social isolation: analysis in light of Hildegard Peplau
}

\author{
Coping em saúde mental durante o isolamento social: análise à luz de Hildegard Peplau \\ Coping en salud mental durante el aislamiento social: análisis a la luz de Hildegard Peplau
}

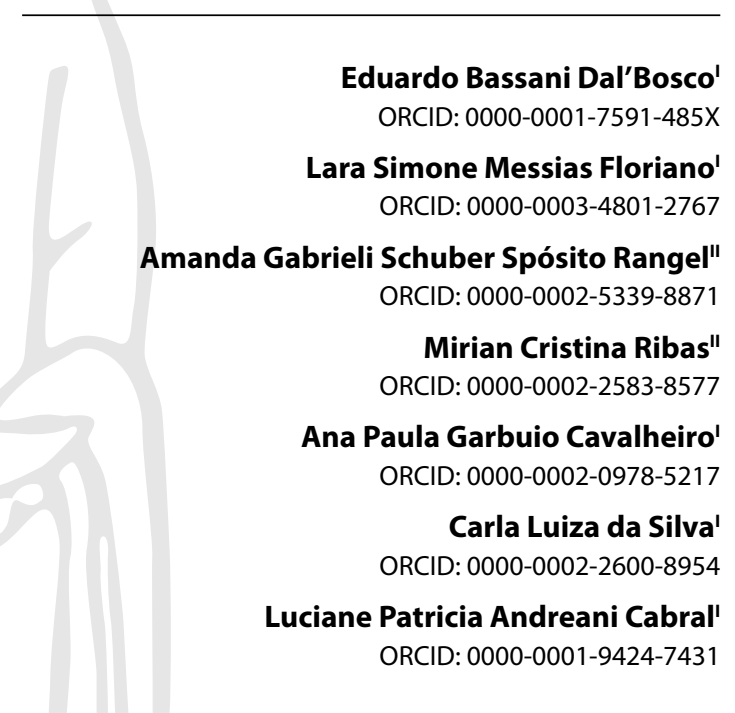

'Universidade Estadual de Ponta Grossa. Ponta Grossa, Paraná, Brazil.

"Hospital Universitário Regional dos Campos Gerais. Ponta Grossa, Paraná, Brazil.

How to cite this article: Dal'Bosco EB, Floriano LSM, Rangel AGSS, Ribas MC, Cavalheiro APG, Silva $C L$, et al. Coping in mental health during social isolation: analysis in light of Hildegard Peplau. Rev Bras Enferm. 2022;75(2):e20201207. https://doi.org/10.1590/0034-7167-2020-1207

Corresponding author:

Eduardo Bassani Dal'Bosco

E-mail: bassani_eduardo@outlook.com

EDITOR IN CHIEF: Dulce Barbosa ASSOCIATE EDITOR: Hugo Fernandes

Submission: 11-13-2020

Approval: 05-09-2021

\section{ABSTRACT}

Objectives: to analyze the coping of individuals in social isolation due to suspicion or confirmation of coronavirus infection from the perspective of Hildegard Peplau's Theory of Interpersonal Relations. Methods: this is a qualitative, descriptive research, carried out with 34 individuals in social isolation due to suspicion or confirmation of coronavirus infection who passed through a screening tent of a university hospital in Paraná. Data were collected through semi-structured interviews in June and July 2020. Empirical categories were interpreted by content analysis. Results: four categories emerged: Distance; Social and emotional support Self-awareness and resolution; Learning. These categories established the coping strategies. Conclusions: individuals undergoing social isolation are more likely to present problems related to mental health. It was highlighted that coping strategies, motivated by nurses, anchored in Hildegard Peplau's theoretical framework, promoted the necessary learning for promoting participants' mental health in the face of a pandemic context.

Descriptors: Coronavirus Infections; Psychological Stress; Psychological Adaptation; Mental Health Nursing; Social Isolation.

\section{RESUMO}

Objetivos: analisar o coping de indivíduos em isolamento social por suspeita ou confirmação de infecção por coronavírus na perspectiva da Teoria das Relações Interpessoais de Hildegard Peplau. Métodos: pesquisa qualitativa, do tipo descritiva, realizada com 34 indivíduos em isolamento social por suspeita ou confirmação de infecção por coronavírus que passaram na tenda de triagem de um hospital universitário paranaense. Os dados foram coletados por entrevista semiestruturada em junho e julho de 2020. As categorias empíricas foram interpretadas pela análise de conteúdo. Resultados: revelaram-se quatro categorias: Afastamento; Suporte social e emocional; Autopercepção e resolução; Aprendizado. Essas categorias estabeleceram as estratégias de coping. Conclusões: concluiu-se que indivíduos submetidos ao isolamento social estão mais suscetíveis a apresentar problemas relacionados à saúde mental. Destacou-se que, estratégias de enfrentamento, motivadas pelo enfermeiro ancorado no referencial teórico de Hildegard Peplau, promoveram o aprendizado necessário para a promoção da saúde mental dos participantes diante do contexto pandêmico. Descritores: Infecções por Coronavírus; Estresse Psicológico; Adaptação Psicológica; Enfermagem em Saúde Mental; Isolamento Social.

\section{RESUMEN}

Objetivos: analizar el afrontamiento de individuos en aislamiento social por sospecha o confirmación de infección por coronavirus desde la perspectiva de la Teoría de las Relaciones Interpersonales de Hildegard Peplau. Métodos: investigación cualitativa, descriptiva, realizada con 34 individuos en aislamiento social por sospecha o confirmación de infección por coronavirus que pasaron por la carpa de cribado de un hospital universitario de Paraná. Los datos fueron recolectados a través de entrevistas semiestructuradas en junio y julio de 2020. Las categorías empíricas fueron interpretadas por análisis de contenido. Resultados: se revelaron cuatro categorías: Retiro; Apoyo social y emocional; Autoconciencia y resolución; Aprendizaje. Estas categorías establecieron las estrategias de afrontamiento. Conclusiones: se concluyó que los individuos en aislamiento social tienen más probabilidades de presentar problemas relacionados con la salud mental. Se destacó que las estrategias de afrontamiento, motivadas por la enfermera, ancladas en el marco teórico de Hildegard Peplau, promovieron el aprendizaje necesario para la promoción de la salud mental de los participantes ante el contexto pandémico.

Descriptores: Infecciones por Coronavirus; Estrés Psicológico; Adaptación Psicológica; Enfermería de Salud Mental; Aislamiento Social. 


\section{INTRODUCTION}

Social isolation, imposed to contain coronavirus infection, increases the risk of individuals in residential or hospital exiles to develop stress due to the change in daily routine, adaptation to the new scenario, community, family and work distancing ${ }^{(1)}$. Stress can be considered by an external or internal causal agent (stressor), coping processes used by the mind and the complex pattern of manifestations of the body and mind, given the stress reaction that exceeds the sources of adaptation of an individual or social system ${ }^{(2)}$.

There is evidence that, when faced with a stressor, the body experiences three phases of change. The first, alert phase, is the phase in which the body identifies a stressor and stimulates the neuroendocrine system. The second phase, adaptation, is the period in which the body repairs the damage caused by the alarm reaction and reduces hormone levels. The third phase, exhaustion, occurs if a stressor remains present, which includes the emergence of a stress-related illness ${ }^{(3)}$. The way of coping with stressful phenomena has immediate and lasting impacts, which can cause risks and damage to mental health ${ }^{(4)}$.

Indeed, stress triggered by the condition of social isolation depends, for its struggle, on personal attributes, such as health and energy, the belief system, life goals, self-esteem, self-control, knowledge, the ability to problem solving, social support practices and the use of coping strategies in the face of stressful conditions - coping ${ }^{(5)}$.

The cognitive perspective of Lazarus \& Folkman (1984) $)^{(6)}$ adopts the concept of coping as a process or interaction that takes place between individual and environment, whose function is not to control or dominate a stressful situation, but to manage it based on how it is perceived, interpreted and cognitively represented in individuals' minds. Thus, there is emotion-focused coping, whose purpose is to regulate the emotion that is linked to stress or is the result of these. Efforts are directed at the somatic or feelings level, seeking to change the emotional state and reduce the uncomfortable physical sensations caused by it - and problem-focused coping - capable of modifying the situation that triggered stress, in order to remedy this difficulty that is between individual and environment, causing tension ${ }^{(7)}$.

Regardless of the type of personal resources, the coping process requires cognitive and behavioral efforts to deal with internal/ external issues that overload or exceed individuals' ability to resolve in the face of stressors and threats to their well-being ${ }^{(8)}$. This process is complex and often requires the intervention of professionals oriented to implement care strategies for emotional and social support.

In this context, the mental health nursing approach based on Hildegard Peplau's Theory of Interpersonal Relations (1952) appears as a possibility of therapeutic support, since it is based on the nurseclient interaction, having as its guiding axis the psychodynamic perspective, arising from nursing knowledge to other knowledge disciplines to promote personality development, towards a creative, constructive, productive, personal and independent life ${ }^{(9)}$.

The basic concepts of Peplau's Theory emerged in 1950 from the spread of constructivism and phenomenology as a possibility to study and explain human phenomena ${ }^{(9)}$. The Theory is structured in four stages: orientation, identification, exploration, and resolution.
In the first stage, there is the meeting of two unknown people (nurse-client), who need to establish communication strategies to understand the facts and attempt to revert the tension and stress energy into something productive for the development of their personality. In the second stage, identification, it is up to nurses to guide individuals to rescue symbols and representations that relate situations of dependence and independence on the phenomenon that generates stress, clarifying the preconception of both and leading to constructive learning. In the third stage, individuals will be able to organize their thoughts with greater independence. It is then up to nurses to listen, clarify and encourage the establishment of new goals. Finally, in the last step, individuals find the resolution or not of the clinical problem, by the disengagement of nurses involved in the therapeutic process and also by individuals' current capacity independently in the face of a stressor ${ }^{(7)}$.

The Theory of Interpersonal Relationships, applied in psychiatric nursing care, is satisfactorily framed in the situation at hand, since the interpersonal relationship, care and guidance for individuals with potential psychological distress (caused by social isolation due to infection by the new coronavirus) subsidize the assistance provided to patients assisted in an extra-hospital service in monitoring through interpersonal, interdisciplinary and community relationships (although through telephone contact, as in the case of this research). Thus, Peplau's theoretical precepts admit transcendence to the physical spaces of hospital institutions and can be applied in all contexts of health care ${ }^{(7)}$.

Considering that people in social isolation due to suspicion or confirmation of coronavirus infection can present stress and that the therapeutic communication practiced by nurses, guided by Hildegard Peplau's Theory of Interpersonal Relations, can help in coping ${ }^{(10)}$ and, with the intention of to improve nursing care and practice ${ }^{(9)}$, the present study was carried out.

\section{OBJECTIVES}

To analyze the coping of individuals in social isolation due to suspicion or confirmation of coronavirus infection from the perspective of Hildegard Peplau's Theory of Interpersonal Relations.

\section{METHODS}

\section{Ethical aspects}

This study was approved by the Institutional Review Board of Universidade Estadual de Ponta Grossa, state of Paraná. The ethical guidelines for voluntary and consenting participation of each participant were respected, in accordance with Resolution 466/2012 $2^{(11)}$ of the Brazilian National Health Board (Conselho Nacional de Saúde).

\section{Study design}

This is a qualitative, descriptive research. Qualitative research allows investigating a reality through various strategies ${ }^{(12)}$, while descriptive research seeks to describe, as accurately as possible, the occurrence of a fact, the relationship with others, characteristics and its nature ${ }^{(13)}$. This study met the steps recommended by the Consolidated criteria for qualitative reporting research (COREQ) ${ }^{(14)}$. 


\section{Study setting}

The study was carried out in a screening tent (external space, field) in a regional university hospital located in Paraná.

\section{Data source}

The sample was selected for convenience, in order to obtain a census of the situation of users in social isolation due to suspicion or confirmation of infection by the new coronavirus, totaling 34 participants.

\section{Data collection and organization}

Data collection took place in the interstice between June and July 2020. The inclusion criteria were: being over eighteen years old, living in the municipality where the study took place, staying in social isolation for fourteen days. The workers of the aforementioned hospital institution, those with incomplete data that did not allow the researchers to invite the research and individuals who did not accept to participate in the study were excluded from the research. After explaining by telephone about the objectives, means of collection, analysis and result of information, individuals, when in agreement and spontaneously, participated by accepting the research.

The research instrument used was a semi-structured interview, containing questions related to participant sociodemographic characterization, through Google Forms, and also with four open questions from a range of coping strategies assessment scale ${ }^{(6)}$. The scale inventory has 66 questions for application in studies where there is a need to identify ways to deal with stress. The adaptation was built and adapted with the four questions, according to the criteria and acceptability of the study's content and objectives.

Under the precepts of therapeutic communication and entirely by telephone, the researchers filled out the survey instrument, as the answers were given by participants, and these answers were organized for further data analysis. The guiding questions were: what difficulties did you encounter during the period of social isolation? What strategies did you use to soothe the situation? Did you feel the need to seek help from a professional or an institution for emotional support? Did you feel the change in your behavior/ mood? Did you manage to handle this situation? How? Did you manage to take advantage of this situation? If so, which ones?

\section{Data analysis}

The technique used for data processing was conducted through content analysis. The content analysis methodology ${ }^{(15)}$ is presented as a set of techniques that, through systematic procedures and data analysis (speech obtained in interviews, indicators, among others), knowledge related to the production, reception and content of this information obtained are inferred.

In solidifying this approach, three phases were passed: preanalysis of the theme, with the understanding of the determinants of the impacts of infection by the new coronavirus and the coping strategies in relation to mental health; material exploration, with the tangible construction of four categories; and, finally, treatment of results, with the description and interpretation of interviews.
The four categories listed as guiding questions were built in: Distance; Social and emotional support; Self-awareness and resolution; Learning. From this, they were fragmented into two sections, description and interpretation of the speeches, systematized in order to order participants' responses and delimit the perceptions extracted from the questions, dialoguing with the relevant literature and the strategies used by individuals to coping with social isolation.

\section{RESULTS}

First, the profile of research participants was gathered. In this study, 67 (sixty-seven) individuals were contacted and the number of refusals was 33 (thirty-three) people. The total sample was 34 (thirty-four) people. The results showed the age group of participants around 44 years of age, ranging between 20 and 85 years, with a prevalence of females ( 25 women), with white race/color (20 people), education with education complete high school (18 people), 'housewife' profession ( 16 people) and monthly income of up to 01 (one) minimum wage (21 people).

Aiming to better articulate coping with the approach chosen to analyze the phenomenon studied, the interview focused on the coping process due to a stressful situation caused by social isolation due to suspicion or confirmation of coronavirus infection ${ }^{(16)}$, with the guiding questions in this study that sought to establish, within the logic of interpersonal relationships brought by Peplau ${ }^{(7)}$, the construction of the empirical categories, presented in the chart below:

Chart 1 - Synthesis of factors and questions to implement the categories

\begin{tabular}{|l|c|}
\hline GUIDING QUESTION & CATEGORIES \\
\hline $\begin{array}{l}\text { What difficulties did you encounter during the } \\
\text { period of social isolation? What strategies did } \\
\text { you use to soothe the situation? }\end{array}$ & Distance \\
\hline $\begin{array}{l}\text { Did you feel the need to seek help from a } \\
\text { professional or an institution for emotional } \\
\text { support? }\end{array}$ & $\begin{array}{c}\text { Social and } \\
\text { emotional } \\
\text { support }\end{array}$ \\
\hline $\begin{array}{l}\text { Did you feel the change in your behavior/mood? } \\
\text { Did you manage to handle this situation? How? }\end{array}$ & $\begin{array}{l}\text { Self-awareness } \\
\text { and resolution }\end{array}$ \\
\hline Did you manage to take advantage of this situation? & Learning \\
\hline
\end{tabular}

From this perspective, the categories resulting from analysis of the interviews, as well as participants' statements, are presented below.

\section{Distance}

In this category found, participants expressed everything related to difficulties and stressful situations due to social isolation due to suspicion or confirmation of coronavirus infection; the main speeches about the distancing factor brought, predominantly, isolation, loneliness:

[...] being totally isolated, alone, made me sad and anxious. (E4)

Anxiety increased, she was already undergoing drug treatment and isolation increased. (E12)

A lot of anxiety. (E2) 


\section{A lot of anxiety and nervousness. (E5) \\ [...] I got depressed, nervous, anxious. (E23)}

Given this, it was found that, with regard to the strategies that participants used to soothe the situation, social networks were the great allies:

[...] reading books, listening to music and reorganizing life. (E4)

Reading to soothe. (E12)

Social networks helped a lot. (E2)

I used the social network to relieve tension. (E5)

I read to calm down. (E23)

[...] / used social networks to soothe. (E30)

Social networks helped a lot. (E17)

I used social media to calm down, pass the time. (E19)

A study shows that social networks are part of the relationships considered significant for individuals, in which the dynamic is analyzed by exploring individuals' statements, which includes investigating structural aspects, for example. This environment presents itself as a relevant factor for individuals who present stressful situations in their daily lives, at work and in the social context ${ }^{(17)}$.

Anxiety issues and nervousness were quite evident in the statements:

Leave of work, I was anxious. (E33)

Nervousness, anxiety, fear of leaving the house. (E15)

Lots of anxiety and nervousness. (E7)

Anxiety, nervousness. (E25)

I was very anxious; I didn't spend time. (E28)

I was anxious, afraid of having the virus and passing it on to the family, I couldn't leave the house, I was in agony. (E18)

We get a little anxious about staying at home, not being able to work or go out. (E2)

Anxious about not being able to work, just staying at home. (E13)

Participants' statements bear important similarities to the Ebola epidemic in 1995, in which the survivors reported major situations of stress, anxiety, fear of dying and/or infecting friends and family, as well as the social stigma of the disease, the distance from the family, home, labor activities and the concern with the duration of the pandemic situation ${ }^{(1)}$.

\section{Social support}

In this category, found from the guiding questions, the needs for social and/or emotional support reported by the participants who did not feel the need to seek help from professionals or institutions for emotional support are presented; however, those who reported having needed it reveal that they sought psychiatrists and psychologists or that they were already using medication:

Yes, I sought psychological care. (E8)

Yes, I looked for a psychiatrist and used two medications. (E24)

[...] he has been following up with a psychiatrist for years. (E14)

No, I already use medication for anxiety. (E26)

Yes, I went to a psychologist. (E19)

Yes, I had an appointment with a psychologist who helped a lot. (E3)

Currently, mental health professionals have made themselves available to provide care, assistance and assistance to those who, in some way, were psychically affected by the pandemic. Services have been carried out, to a large extent, through platforms (online) or by telephone contact, aiming at providing support, mitigation and/or prevention of future mental problems ${ }^{(18)}$.

\section{Self-awareness and resolution}

In this category, study participants highlighted the feelings of sadness, anxiety and fear:

[...] a little depressed. (E23)

Yes, I was sad. (E22)

A little saddened. (E5)

Just anxiety. (E32)

Sadness, fear. (E11)

Fear of catching and contaminating others. (E17)

He was a little afraid of being contaminated. (E26)

Only anxiety itself. (E34)

I was a little sad, nervous, anxious. (E1)

A little afraid of having the coronavirus and passing it on to the family. (E9)

[...] only anxiety and desire to leave. (E10)

A little nervous at times. (E21)

The sentimental variables brought up by the participants are stressors commonly described in the literature for affected populations, since the pandemic promotes uncertainty, fear, sadness, anxiety and instability in daily activities, which can lead to emotional, cognitive and behavioral changes ${ }^{(19)}$. 


\section{Learning}

In the fourth and last category arising from analysis of all interviews, it was evident that the participants were able to take advantage of the situation from reflections on life and its valuation, the approximation with their families:

\section{[...] approximation of the family, of the son. (E31)}

Reflection on life, on the family, thinking more about health and not material goods. (E6)

Yes, reflection on life, organization, thinking about studying more, taking a course. (E16)

We evaluate the things in life better, what we have. (E27)

Thinks more about life, gives more value to what you have. (E10)

[...] thinks and values the things in life more. (E23)

[...] family approximation. (E29)

Yes, approximating to the family, thinking about life. (E30)

Thinks more about the things in life, family. (E11)

We think a lot about the family, about the things we have, we thank God. (E7)

Got closer to the family. (E4)

Spend more time with the family and be thankful for the things in life. (E12)

Ispend more time with my family, thanking what I have in life. (E20)

Yes, I got closer to the family, I had time to reflect on life, good things that we have. (E21)

\section{[...] I think approximating to the family, thinking about life. (E14)}

Yes, it approximated the family. (E32)

[...] yes, you could think about life, be grateful for what you have. (E9)

I spent more time with my family. (E20)

From the perceptions and statements obtained in this research, it was observed that individuals undergoing social isolation are more likely to present mental health problems due to social containment/isolation, with problems related to stress, depression and anxiety as well as the need for emotional support. Considering the urgency of alleviating the impacts generated in the pandemic context, mental health promotion is used as a strategy for coping with the behavioral changes of individuals, perpetuating the psychological effects of social isolation in the face of resilience, self-compassion, creativity, optimism, hope, and subjective well-being ${ }^{(20)}$.

\section{DISCUSSION}

This research showed that the participants went through three stages, distancing, the need for social and emotional support and self-awareness, in the face of social isolation due to suspicion or confirmation of coronavirus infection. These steps were fundamental for the achievement of Learning, the last category presented in this study, for the establishment of coping strategies, which are discussed below:

In the first category, the presence of loneliness, anxieties, sadness, anxieties, factors caused by social isolation, was observed. These difficulties caused stress arising from the situation experienced. In this context, it is highlighted that people can suffer, at various levels of intensity, severe psychological and social impacts ${ }^{(21-22)}$.

There are reports in the literature about major situations of stress, anxiety, fear of dying and/or infecting friends and family, as well as the social stigma of the disease, distancing from family, home, work activities and concern about the duration of the pandemic situation ${ }^{(1)}$, providing a negative impact on the lives of those involved. In another study ${ }^{(23)}$, anxiety was preponderant, especially in healthy individuals. Also, taking into account that the transmission of the virus occurs through personal contact, usually family members are separated from their relatives, in order to avoid contagion.

In the second category, there is the initial presence of denial of seeking help from the health professional, but it is noticed that, after, users sought professional help. Seeking help and help strategies for a stressor can change the experienced stress situation ${ }^{(23)}$.

It is understood that family support is essential, in order to create managements to strengthen individuals' mental health. This study revealed that family approximation, based on social isolation ${ }^{(22)}$, was important for overcoming and coping with the experienced moment.

Another beneficial tool is the use of trustworthy social media, in order to reassure people in social isolation. A study ${ }^{(24)}$ highlighted the positive effect caused and its possible relationship with altruism, considerably reducing its psychological impact and, consequently, lower levels of stress and anxiety. Another point raised is the practice of regular physical activity during the pandemic, which can help to control anxiety ${ }^{(21,25)}$.

From the perspective of maintaining mental health and sustaining emotional balance, the relevance of some psychotherapeutic managements through countless techniques, exercises or tools with the purpose of maintaining good mental health in this context is highlighted. In this study, the reorganization of the routine, the search for rest, reflections about life, prayers, activities such as reading, music, among others were reported on these approaches to coping with social isolation ${ }^{(26)}$.

Strengthening these notes, the World Health Organization (WHO) recommends daily physical exercise, with the purpose of reducing anxiety and maintaining mobility, to avoid the consequences that isolation can cause. It emphasizes the importance of instituting other activities, such as good reading, listening to music, dancing, painting, among others that can be maintained to improve the routine. Another valuable aspect is the strengthening of empathy and solidarity with others, virtually or even offering some support and help that can soothe psychological distress ${ }^{(27-28)}$. 
In the third category, it was possible to evidence behavioral changes, feelings of sadness, anxiety, fear and nervousness with the uncertain. Such behavioral changes are stressors that end up promoting fear and sadness, causing changes in individuals'behavior ${ }^{(19)}$.

In this aspect, these behavioral change problems reported by participants can be observed in research ${ }^{(29)}$, which indicates changes in sleep, in contact with people, perception of increased family stress, as well as the concern with family income that caused friction among family members ${ }^{(29)}$.

Finally, in the fourth category, it was possible to verify that participants were able to score positive situations of family approximation, reflection on life, valuing simple situations of affection and gratitude. Thus, this "bright" side can lead individuals to develop strategies that help them to face problems, reducing suffering, providing opportunities to understand the meaning of life in a more positive way in the face of stressful situations. In this sense, the authors point out that positive situations can be understood as a form of resilience to face problems ${ }^{(20)}$.

\section{Study limitations}

Limitations are verified in the self-report for the answers inherent to the guiding question and to the investigation of a single region. The potential of this investigation is based on the projection for future studies on mental adaptation and human resourcefulness in overcoming crisis contexts, since the participants of this study reported mostly having promoted coping strategies by themselves without help of professionals and institutions. It appears that the potential may have been determined by the specifications imposed by the pandemic itself.

\section{Contributions to psychiatric nursing and mental health}

This study analyzed the main coping strategies of people in social isolation due to suspicion or confirmation of coronavirus infection, under Hildegard Peplau's theoretical approach. In the face of nursing practice, it must be thought of from a humanist, creative and reflective perspective, considering care as a central category of the profession, involved as a dynamic, changeable and innovative process.
Thus, this study intended to contribute to the dissemination of the importance of interconnected nursing practices in the care process in the face of the pandemic scenario, considering the relevance of the theme guided by nursing theories in mental health, contributing to the improvement and advancement of knowledge in the area.

\section{CONCLUSIONS}

Faced with the difficulties arising from an unfinished pandemic context, users subjected to situations of social isolation presented feelings of sadness and fear, combined with prognoses of anxiety and stress. To soothe such circumstances, the most used mechanisms were reading, social networks, physical activity, family approximation and the appeal to religiosity, corroborating the representation of the 'problem' and 'emotion' pillar brought by Lazarus and Folkman (1984).

Considering the perspective of the pandemic scenario, nursing professionals play a fundamental role in the care given to stressful factors, since they are present most of the time and know the fears, anxieties and problems that individuals have. Therefore, it is essential that nursing care submerges affection with oneself and with the other, involving seeing with the heart in all its particularity and plenitude.

In this aspect, Peplau's Theory is an important instrument in care, considering the moment experienced in the pandemic. This way of thinking and acting in nursing helps with the difficulties that patients present as well as strengthens the interpersonal relationship in solving the problems that arise at the time of care. Rooting nursing practice based on science and theory provides nurses with breadth and autonomy in the face of problems encountered in the pandemic.

Thus, given the global impact and the exponential increase in cases of people infected by the new coronavirus, this study boosts the importance of other behavioral and psychological analyzes of health service users and the deepening of other strategies that can contribute to strengthening health and coping with social tensions, since the pandemic represents, so far, one of the greatest health challenges of the $21^{\text {st }}$ century.

\section{REFERENCES}

1. Schmidt B, Crepaldi MA, Bolze SDA, Neiva-Silva L, Demenech LM. Saúde mental e intervenções psicológicas diante da pandemia do novo coronavírus (COVID-19). Estud Psicol (Campinas). 2020;37:e200063. https://doi.org/10.1590/1982-0 275202037e200063

2. Graça CC, Zagonel IPS. Estratégias de coping e estresse ocupacional em profissionais de enfermagem: revisão integrativa. Rev Espaço Saúde. 2019;20(2):67-77. https://doi.org/10.22421/15177130-2019v20n2p67

3. Lazzaroto PK, Celich KLS, Souza SS. Estratégias de enfrentamento utilizadas pela equipe de enfermagem no cuidado ao paciente oncológico e família. Rev Enferm UFSM. 2018;8(3):560-75. https://doi.org/10.5902/2179769229408

4. Lima RC. Distanciamento e isolamento sociais pela Covid-19 no Brasil: impactos na saúde mental. Physis. 2020;30(2):e300214. https://doi. org/10.1590/s0103-73312020300214

5. Facchinetti NS. Contribuições da meditação mindfulness como estratégia de coping para lidar com o estresse em relação à comida[Dissertação] [Internet]. Escola Bahiana de Medicina e Saúde Pública. 2015[cited 2020 Jul 14]. Available from: http://www7.bahiana. edu.br/jspui/bitstream/bahiana/273/1/Disserta\%C3\%A7\%C3\%A3o.\%20Facchinetti.\%20Norma\%20Suely.\%202015.001.\%20BAHIANA.pdf

6. Folkman S, Lazarus RS. If it changes it must be a process: Studyofemotionandcopingduringthreestagesofcollegeexamination. J Personal Soc Psychol. 1984;48(1):150-70. https://doi.org/10.1037/0022-3514.48.1.150 
7. Cardoso TVM, Oliveira RMP, Loyola CMD. [An agreement about the Peplau's Theory and the principles of the Brazilian Psychiatric Reformation]. Esc Anna Nery. 2006;10(4):718-24. https://doi.org/10.1590/S1414-81452006000400014 Portuguese.

8. Dias EM, Ribeiro JLP. O Modelo de Coping de Folkman e Lazarus: aspectos históricos e conceituais. Rev Psicol Saúde. 2019;11(2):55-66. https://doi.org/10.20435/pssa.v11i2.642

9. Pinheiro CW, Araújo MAM, Rolin KMC, Oliveira CM, Alencar AB. Teoria das relações interpessoais: reflexões acerca da função terapêutica do enfermeiro em saúde mental. Enferm Foco [Internet]. 2019[cited 2021 Mar 14];10(3):64-9. Available from: http://revista.cofen.gov.br/index. php/enfermagem/article/view/2291/580

10. Coelho MTV, Siqueira C. Comunicação terapêutica em enfermagem: como a caracterizam os enfermeiros. Rev Port Enferm Saúde Mental. 2014;11(3):31. Available from: http://www.scielo.mec.pt/pdf/rpesm/n11/n11a05.pdf

11. Ministério da Saúde (BR). Resolução no 466/2012. Diretrizes e normas regulamentadoras de pesquisas envolvendo seres humanos [Internet]. 2012[cited 2021 Mar 14]. Available from: https://bvsms.saude.gov.br/bvs/saudelegis/cns/2013/res0466_12_12_2012.html

12. Creswell JW. Projeto de pesquisa: métodos qualitativo, quantitativo e misto. 3a ed. Porto Alegre: Artmed; 2010.

13. Rampazzo L. Metodologia científica: para alunos dos cursos de graduação e pós-graduação. 3a ed. São Paulo: Loyola; 2005.

14. Tong A, Sainsbury P, Craig J. Consolidated criteria for reporting qualitative research (COREQ): a 32-item checklist for interviews and focus groups. Int J Qual Health Care. 2007[cited 2016 Dec 12];19(6):349-57. Available from: https://academic.oup.com/intqhc/article-lookup/ doi/10.1093/intqhc/mzm042

15. Bardin L. Análise de conteúdo. São Paulo: Edições 70. 2011.

16. Savoia MG, Amadera RD. Utilização da versão brasileira do inventário de estratégias de coping em pesquisas da área da saúde. Psicol Hosp. 2016[cited 2021 Mar 14];14(1):117-38. Available from: http://pepsic.bvsalud.org/scielo.php?script=sci_arttext\&pid $=\mathrm{S} 167774092016000100007$

17. Azevedo AVS, Crepaldi MA. Enfrentamento e redes sociais significativas de familiares cuidadores de crianças com queimaduras. Bol Acad Paul Psicol [Internet]. 2019[cited 2021 Mar 14];39(97). http://pepsic.bvsalud.org/pdf/bapp/v39n97/a03v39n97.pdf

18. Faro A, Bahiano MA, Nakano TC, Reis C, Silva BFP, Vitti LS. COVID-19 e saúde mental: a emergência do cuidado. Estud Psicol (Campinas). 2020;37:e200074. https://doi.org/10.1590/1982-0275202037e200074

19. Enumo SRF, Weide JN, Vicentini ECC, Araujo MF, Machado WL. Enfrentando o estresse em tempos de pandemia: proposição de uma Cartilha. Estud Psicol (Campinas). 2020;37:e200065. https://doi.org/10.1590/1982-0 275202037e200065

20. Zanon C, Dellazzana-Zanon LL, Wechsler SM, Fabretti RR, Rocha KN. COVID-19: implicações e aplicações da Psicologia Positiva em tempos de pandemia. Estud Psicol (Campinas). 2020;37:e200072. https://doi.org/10.1590/1982- 0275202037e200072

21. World Health Organization (WHO). Q\&A on coronaviruses (COVID-19) [Internet]. 2020[cited 2021 Mar 14]. Available from: https://www.who. int/emergencies/diseases/novel-coronavirus-2019/question-and-answers-hub/q-a-detail/q-a-coronaviruses

22. Fundação Oswaldo Cruz (Fiocruz). Cartilha Saúde Mental e Atenção Psicossocial: Informações Gerais [Internet]. 2020[cited 2021 Mar 14]. Available from: https://portal.fiocruz.br/documento/cartilha-saude-mental-e-atencao-psicossocial-na-pandemia-covid-19

23. Fetsch CFM, Portella MP, Kirchner RM. Estratégias de Coping entre Familiares de Pacientes Oncológicos. Rev Bras Cancerol. 2016;62(1):17-25. https://doi.org/10.32635/2176-9745.RBC.2016v62n1.175

24. Ramírez-Ortiz J, Castro-Quintero D, Lerma-Córdoba C, Yela-Ceballos F, Escobar-Córdoba, F. Consecuencias de la pandemia COVID-19 en la Salud Mental asociadas al aislamiento social. 2020. SciELO Preprints:1-21. https://doi.org/10.1590/SCIELOPREPRINTS.303

25. Ho CS, Chee CY, Ho RC. Mental health strategies to combat the psychological impact of COVID-19 beyond paranoia and panic. Ann Acad Med Singapore [Internet]. 2020[cited 2021 Mar 14];49(3):155-60. https://pubmed.ncbi.nlm.nih.gov/32200399/

26. Wang Y, Zhao X, Feng Q, Liu L, Yao Y, Shi J. Psychological assistance during the coronavirus disease 2019 outbreak in China. J Health Psychol. Preprints:1-5. https://doi.org/10.1177/1359105320919177

27. Ribeiro EG, Souza EL, Nogueira JO, Eler R. Saúde Mental e COVID-19 Saúde Mental na Perspectiva do Enfrentamento à COVID-19: manejo das consequências relacionadas ao isolamento social. Rev Enferm Saúde Colet FSP [Internet]. 2020[cited 2020 Sep 06];4(2):47-57. https:// www.revesc.org/index.php/revesc/article/view/59/68\#

28. Organização Mundial de Saúde OMS. Organização Pan-Americana de Saúde OPAS. Folha informativa COVID-19 - 2020: doença causada pelo novo coronavírus [Internet]. 2020[cited 2020 Sep 06]. Available from: https://www.paho.org/pt/covid19

29. Bezerra ACV, Silva CEM, Soares FRG, Silva JAM. Fatores associados ao comportamento da população durante o isolamento social na pandemia de COVID-19. Ciênc Saúde Colet. 2020;25(Suppl 1):2411-21. https://doi.org/10.1590/1413-81232020256.1.10792020 